УДК 347.44:347.15/17(477)

\author{
О. Я. Кузьмич
}

\title{
ПРАВОВІ ПОЛОЖЕННЯ ЩОДО УЧАСТІ ТРЕТІХ ОСІБ У ЗОБОВ'ЯЗАННЯХ ЗІ СТВОРЕННЯ ЗАГРОЗИ ЖИТТЮ, ЗДОРОВ'Ю, МАЙНУ ФІЗИЧНОЇ ОСОБИ АБО МАЙНУ ЮРИДИЧНОЇ ОСОБИ
}

Постановка проблеми. Як свідчить аналіз доктринальних досліджень, юридична природа зобов'язань зі створення загрози життю, здоров'ю, майну фізичної особи або майну юридичної особи (глава 81 ЦК України) неодноразово ставала предметом уваги з боку науковців, однак і до сьогоднішнього дня чимало питань юридичної природи таких зобов'язань, про що свідчить аналіз доктринальних досліджень, залишаються дискусійними, одним з яких $є$ питання з приводу можливості участі в таких зобов'язаннях третіх осіб як суб’єктів цивільних правовідносин.

Оцінка стану літератури. Як свідчить аналіз юридичної літератури, на сучасному етапі розвитку науки цивільного права питання зобов'язань зі створення загрози життю, здоров'ю, майну фізичної особи або майну юридичної особи (глава 81 ЦК України) досліджувалися в працях В.В. Луця, Є.О. Мічуріна, М.Р. Габріадзе, О.О. Отраднової тощо, однак що стосується питань участі в таких правовідносинах третіх осіб, то вони, як правило, залишалися поза увагою.

Формулювання мети та завдань дослідження. 3 огляду на специфіку правового регулювання зобов'язань зі створення загрози життю, здоров'ю, майну фізичної особи або майну юридичної особи (глава 81 ЦК України), а також розуміння третіх осіб як суб'єктів цивільних правовідносин основним завданням цього наукового дослідження буде визначення можливості участі в таких правовідносинах третіх осіб.

Виклад основного матеріалу. Надавши правову регламентацію цьому інституту, законодавець в ч. 1 ст. 1163 ЦК України відзначає, що фізична особа, життю, здоров'ю або майну якої загрожує небезпека, а також юридична особа, майну якої загрожує небезпека, мають право вимагати іiі усунення від того, хто ії створює. Як зауважив В.В. Луць, діяльність деяких суб'єктів господарювання (юридичних, фізичних осіб) іноді пов'язана зі створенням загрози життю, здоров’ю, майну фізичної особи або майну юридичної особи (викиди шкідливих речовин, радіаційне або хімічне за- 
бруднення навколишньої території тощо). У попередженні та ліквідації шкідливих наслідків такої діяльності можуть застосовуватися заходи екологічного, адміністративного чи кримінального характеру. Немаловажну роль тут можуть відігравати і норми цивільно-правового інституту усунення загрози життю, здоров'ю фізичної особи або майну юридичної особи [4, с. 227]. Не чикаючи шкодонесучих наслідків, як пише Є.О. Мічурін, фізична особа, життю, здоров’ю або майну якої загрожує небезпека, в силу ст. 1163 ЦК України мають право вимагати іï усунення від того, хто ї створює. На відміну від загального правила, згідно з яким деліктне зобов'язання виникає внаслідок настання шкоди як одного з необхідних елементів деліктної відповідальності, в деяких випадках, завважується автором, лише створення такої небезпеки породжує недоговірне зобов'язання $[5$, с. 360].

Встановлення в цивільному законодавстві таких зобов'язань, як відзначається О.Є. Кухарєвим, обумовлюється перенесенням центру ваги зі шкідливого результату на більш ранній ступінь, коли протиправне діяння лише створює можливість заподіяння шкоди або коли сама діяльність має небезпечні властивості [3, с. 206]. У главі 81 ЦК України, завважується автором, мова йде про два види зобов'язань - зобов'язання, що виникають унаслідок створення загрози завдання шкоди, та зобов'язання з відшкодування шкоди, завданої внаслідок неусунення такої загрози, що, безперечно, впливає на підстави ї виникнення [3, с. 207]. Для першого виду зобов'язань достатньою умовою їх настання $€$ факт створення загрози життю, здоров’ю, майну фізичної особи або майну юридичної особи. При цьому категорії «загроза» та «ризик», завважується О.Є. Кухарєвим, наближаються. За наявності шкоди, завданої неусуненням загрози життю, здоров'ю, майну фізичної особи або майну юридичної особи, зобов'язання виникає за наявності таких підстав: наявність шкоди; протиправна поведінка (дія або бездіяльність) особи, якою створена загроза, що надалі призвела до завдання шкоди; неусунення загрози життю, здоров’ю, майну фізичної особи або майну юридичної особи на вимогу заінтересованої особи; причинний зв’язок між поведінкою (дією або бездіяльністю), якою створено загрозу, і подальшим іï неусуненням та шкодою, яку зазнала заінтересована особа [3, с. 209]. Тобто, як відзначається автором, визначати підстави виникнення зобов'язань внаслідок створення загрози життю, здоров'ю, майну фізичної особи або майну юридичної особи варто з урахуванням їх класифікації на два види: зобов'язання, що виникають унаслідок створення загрози завдання шкоди, та зобов'язання з відшкодування шкоди, завданої внаслідок неусунення такої загрози. Водночас загроза розглядається як ризик настання певних негативних наслідків (шкоди) в майбутньому. При цьому загроза повинна бути наявною і реальною настільки, щоб створювати небезпеку завдання шкоди заінтересованій особі. Реальність небезпеки обумовлюється характером поведінки боржника. Утім, як відзначається, загроза є суб'єктивним фактором, що повністю залежить від сприйняття окремим суб'єктом діяльності інших осіб [3, с. 207]. 
Суб'єктами (сторонами) зобов'язання, що виникає зі створення загрози, є, з одного боку, управомочена особа - кредитор, якому загрожує певна небезпека, а з другого - боржник, який своїми діями створив цю загрозу [4, с. 227]. Підставою виникнення такого зобов'язання можуть бути як дії, так і бездіяльність учасників цивільних відносин. Як кредитором, так і боржником у цьому зобов'язанні можуть бути і фізичні, і юридичні особи. Жодних обмежень в правосуб'єктності для фізичних осіб у межах аналізованого виду зобов'язання законодавець не передбачає.

3 приводу можливості інших учасників цивільних відносин бути сторонами такого зобов'язання, зокрема з тих, про які йдеться в ч. ч. 1,2 ст. 2 ЦК України. Як відзначив М.Р. Габріадзе, держава з огляду на положення ст. 1163 ЦК України потерпілим суб’єктом у цьому виді цивільно-правових зобов'язань виступати не може. Такий висновок, як вважає автор, випливає з формулювання назви глави 81 ЦК України (створення загрози життю, здоров'ю, майну фізичної особи або майну юридичної особи), а також 3 найменування та змісту норм цієї глави, де говориться про «створення загрози життю, здоров’ю, майну фізичної особи або майну юридичної особи». Але, крім того, такий висновок, зауважується, випливає ще із того загального положення, що в ст. 2 ЦК України держава, Автономна республіка Крим, територіальні громади взагалі не іменуються «особами». Із цих міркувань, вважає автор, відповідно до концепції ЦК України держава, Автономна Республіка Крим, територіальні громади, інші соціально-публічні утворення не можуть виступати як окремий, самостійний суб’єкт, майну якого створено небезпеку. Натомість, очевидно, таким суб'єктом можуть бути окремі юридичні особи, що є самостійними учасниками цивільних відносин, але не представляють у даному випадку державу чи інші соціально-публічні утворення [2, с. 15].

Крім того, на таких самих засадах, як пише М.Р. Габріадзе, боржниками можуть стати Автономна Республіка Крим, органи місцевого самоврядування тощо [2, с.16].

Що стосується обсягу суб'єктивних прав та обов'язків, які виникають у сторін цього зобов'язання, то необхідно відзначити, що з моменту виникнення такого зобов'язання в боржника виникає суб'єктивний обов'язок усунути загрозу, якому відповідає право вимоги кредитора. Невиконання боржником такого обов'язку буде підставою для виникнення в нього інших обов'язків, із відповідним правом вимоги кредитора, зокрема, як передбачено ч. 1 ст. 1164 ЦК України, в разі неусунення загрози життю, здоров’ю, майну фізичної особи або майну юридичної особи заінтересована особа має право вимагати : 1) вжиття невідкладних заходів щодо усунення загрози; 2) відшкодування завданої шкоди; 3) заборони діяльності, яка створює загрозу.

Отож, як випливає зі специфіки зобов'язань, про які йдеться, а також розуміння третіх осіб як суб'єктів цивільного правовідношення, які діють від власного імені чи найменування, можуть володіти самостійними правами та (або) обов'язками, а також мають самостійний інтерес, юридична 
природа зобов'язань зі створення загрози життю, здоров'ю, майну фізичної особи або майну юридичної особи (глава 81 ЦК України) є такою, яка виключає участь у них третіх осіб.

3 огляду на відсутність будь-яких обмежень у правосуб'єктності сторін аналізованого виду цивільних правовідносин, виникає запитання з приводу особливостей усунення загрози, яка виходить від осіб із вадами в цивільній дієздатності. Даючи відповідь на поставлене запитання, не можна не звернути увагу на позиції, які висловлені із цього приводу в юридичній літературі. Так, як пише В.В. Луць, якщо загрозу створила недієздатна або обмежено дієздатна особа, вимога щодо усунення загрози має бути звернена до осіб, які несуть відповідальність за наслідки поведінки малолітніх, обмежено дієздатних, недієздатних осіб (батьків, опікунів, піклувальників тощо) [4, с. 227]. Аналогічна думка висловлена й М.Р. Габріадзе. Як вважає автор, у випадках створення загрози неделіктоздатними особами обов'язок відшкодування шкоди покладається на осіб, вказаних у законі, батьків, усиновлювачів, опікунів, піклувальників (з певними обмеженнями), на заклади, під наглядом яких перебували зазначені особи, тощо. Крім того, в деяких випадках обов'язок відшкодування шкоди покладається на державу, яка зобов'язана відшкодувати шкоду, завдану внаслідок створення загрози протиправними діями чи бездіяльністю посадових або службових осіб державних органів, самих державних органів, судових та правоохоронних органів [2, с. 15].

Отож, як випливає з наведеного, а також специфіки аналізованого правовідношення, в разі виникнення загрози з боку осіб, які мають вади в цивільній дієздатності усунення такої загрози за загальним правилом, має здійснюватися безпосередньо їхніми законними представниками, яких, 3 огляду на специфіку інституту законного представництва, підстав для визнання в якості третіх осіб, немає.

3 огляду на специфіку аналізованого правового інституту, а також можливості в окремих випадках усунення загрози особами, які не мали безпосереднього відношення до створення такої загрози, а саме особами, які є законними представниками останніх, виникає запитання з приводу можливості усунення відповідної загрози безпосередньо особами, які не є законними представниками і водночас не мали ні безпосереднього, ні опосередкованого відношення до виникнення відповідної загрози, тобто третіми особами? Як уже відзначалося, можливість покладення виконання (ч. 1 ст. 528 ЦК України) як правова конструкція може використовуватися суб'єктами цивільних правовідносин як щодо зобов'язань, які виникають із договорів, так і недоговірних зобов'язань, винятком із правила можуть бути хіба що обмеження, які випливають із специфіки кожного із зобов'язань. Враховуючи, що для кредитора в даному зобов'язанні немає суттєвого значення, чи така загроза усунута буде безпосередньо боржником особисто, чи залученою ним третьою особою на підставі ч. 1 ст. 528 ЦК України, відповідь на поставлене запитання в частині можливості покладення виконання (ч. 1 ст. 528 ЦК України) має бути позитивною. Інше питання, чи специфіка існуючої загрози дозволятиме залучати боржникам третіх осіб. 
3 іншого боку, передумовою виникнення небезпеки може бути й загроза з боку фізичних чи юридичних осіб, усунення якої може призвести до усунення небезпеки, яка загрожувала фізичній особі, життю, здоров'ю або іiі майну. Водночас, якщо усунення такої небезпеки здійснюватиметься через дії, які кваліфікуватимуться як крайня необхідність чи необхідна оборона, то чи будуть в даному випадку підстави для визнання відповідних осіб, дії яких охоплюються конструкцією необхідної оборони чи крайньої необхідності в якості третіх осіб?

Так, згідно із ч. 1 ст. 1171 ЦК України шкода, завдана особі у зв’язку з вчиненням дій, спрямованих на усунення небезпеки, що загрожувала цивільним правам чи інтересам іншої фізичної або юридичної особи, якщо цю небезпеку за даних умов не можна було усунути іншими засобами (крайня необхідність), відшкодовується особою, яка ії завдала. Особа, яка відшкодувала шкоду, має право пред’явити зворотну вимогу до особи, в інтересах якої вона діяла.

Враховуючи обставини, за яких було завдано шкоди в стані крайньої необхідності, суд може покласти обов'язок ііі відшкодування на особу, в інтересах якої діяли особи, яка завдала шкоди, або зобов'язати кожного з них відшкодувати шкоду в певній частці, або звільнити їх від відшкодування шкоди частково або в повному обсязі (ч. 2 ст. 1171 ЦК України).

Необхідність в юридичній літературі визначається як стан, за якого для усунення небезпеки виникнення шкоди охоронюваним законом правам чи інтересам іншого учасника цивільних відносин особа змушена завдати шкоди учасникам цивільних відносин, не пов'язаних зі створенням загрози, оскільки зазначену небезпеку за даних умов відвернути іншими засобами було неможливо [1, с. 10].

Таким чином, як випливає з наведеного, вчинення дій, які спрямовані на усунення небезпеки, може мати місце як у власному інтересі, так і в чужому, тому у випадку, якщо небезпека випливала із існуючої загрози, і з усуненням такої небезпеки усувалася й загроза, тому усунення останньої може мати місце й через вчинення дій з боку осіб, які не є сторонами цього зобов'язання.

Аналогічний висновок необхідно зробити й в контексті необхідної оборони як правової категорії. Зокрема, необхідна оборона полягає в завданні шкоди правопорушнику з метою припинити правопорушення і захистити власний інтерес. Завдання шкоди в стані крайньої необхідності припускає завдання шкоди невинній особі з метою відвернення небезпеки, за умови, що завдана шкода менша, ніж та, яка загрожувала [6, с. 264]. Так, згідно із ч. 1 ст. 1169 ЦК України шкода, завдана особою під час здійснення нею права на самозахист від протиправних посягань, у тому числі в стані необхідної оборони, якщо при цьому не були перевищені ії межі, не відшкодовується. Крім того, як передбачено ч. 2 аналізованої правової норми, якщо в разі здійснення особою права на самозахист вона завдала шкоди іншій особі, ця шкода має бути відшкодована особою, яка ії завдала. Якщо такої шкоди завдано способами самозахисту, які не заборонені законом та не 
суперечать моральним засадам суспільства, вона відшкодовується особою, яка вчинила протиправну дію.

Як випливає з наведеного, в окремих випадках і необхідна оборона, і крайня необхідність є такими, які можуть бути наслідками вчинення дій у чужому інтересі, тобто на момент вчинення відповідних дій той чи інший учасник цивільних відносин, який діє в чужому інтересі, не є суб'єктом цивільного правовідношення, що є важливим для визнання тих чи інших учасників цивільних відносин (ст. 2 ЦК України) в якості третіх осіб, а отже, підстав для визнання його в якості третьої особи щодо аналізованого виду цивільного правовідношення не буде.

Що стосується відшкодування шкоди (п. 2 ч. 1 ст. 1164 ЦК України) як одного з правових наслідків неусунення загрози життю, здоров’ю, майну фізичної особи або майну юридичної особи, то в цьому випадку, як передбачено ч. 1 ст. 1165 ЦК України, така шкода відшкодовуватиметься за правилами про відшкодування шкоди, які передбачені в загальних положення ЦК України (глава 81 ЦК України).

Висновки i перспективи подальших наукових досліджень. Отож, як випливає зі специфіки зобов'язань, про які йдеться, а також розуміння третіх осіб як самостійних суб'єктів цивільного правовідношення, які діють від власного імені чи найменування, можуть володіти самостійними правами та (або) обов’язками, а також мають самостійний інтерес юридична природа зобов'язань зі створення загрози життю, здоров’ю, майну фізичної особи або майну юридичної особи (глава 81 ЦК України) є такою, яка виключає участь у них третіх осіб. Не допускає участі третіх осіб специфіка правовідносин, про які йдеться, й у випадку усунення загрози, яка виходить від осіб з вадами у цивільній дієздатності, їхніми законними представниками, а також усунення такої загрози іншими особами, які не виступають ні сторонами такого правовідношення, ні законними представниками осіб з вадами в дієздатності, від яких виходила загроза.

\section{Література}

1. Волков О.А. Зобов’язання відшкодування шкоди, завданої в стані крайньої необхідності за цивільним законодавством України : автореф. дис. на здобуття наук. ступеня канд. юрид. наук : спец. 12.00.03 «Цивільне право та цивільний процес; сімейне право; міжнародне приватне право» / О.А. Волков. - Одеса, 2009. - 22 с.

2. Габріадзе М.Р. Зобов'язання, що виникають внаслідок створення загрози життю, здоров'ю, майну фізичної особи або майну юридичної особи, у цивільному законодавстві України : автореф. дис. на здобуття наук. ступеня канд. юрид. наук : спец. 12.00.03 «Цивільне право та цивільний процес; сімейне право; міжнародне приватне право» / М.Р. Габріадзе. K., 2007. - 22 c.

3. Кухарєв О.Є. Підстави виникнення зобов'язань унаслідок створення загрози життю, здоров'ю, майну фізичної особи або майну юридичної особи / O.Є. Кухарєв / / Право і безпека. № 2 (34). - 2010. - С. 205 .

4. Луць В.В. Строки і терміни у цивільному праві : монографія / В.В. Луць. - К. : Юрінком Інтер, 2013. - $320 \mathrm{c}$

5. Мічурін Є.О. Обмеження майнових прав фізичних осіб (теоретико-правовий аспект) : монографія / Є.О. Мічурін. - Х. : Юр світ, НДІ Приватного права та підприємництва АПрН України, 2008. - 482 с. 
6. Чернат В.А. Зобов'язання внаслідок рятування здоров'я та життя фізичної особи / В.А. Чернат / / Актуальні проблеми держави і права. - 2005. - Вип. 25. - С. 260.

\section{Ано о а ці я}

Кузьмич О. Я. Правові положення щодо участі третіх осіб у зобов'язаннях зі створення загрози життю, здоров'ю, майну фізичної особи або майну юридичної особи. Стаття.

Стаття присвячена питанням можливої участі третіх осіб у зобов'язаннях зі створення загрози життю, здоров'ю, майну фізичної особи або майну юридичної особи, з огляду на особливості правового регулювання останніх та розуміння третіх осіб як суб'єктів цивільних відносин.

Ключові слава: третя особа, фізична особа, юридична особа, майно, держава, інша особа.

\section{Анн нот а ция}

Кузьмич О. Я. Правовые положения относительно участия третьих лиц в обязательствах по созданию угрозы жизни, здоровью, имуществу физического лица или имуществу юридического лица. - Статья.

Статья посвящена вопросам возможного участия третьих лиц в обязательствах по созданию угрозы жизни, здоровью, имуществу физического лица или имуществу юридического лица, учитывая особенности правового регулирования последних и понимание третьих лиц как субъектов гражданских отношений.

Ключевые слава: третье лицо, физическое лицо, юридическое лицо, имущество, государство, другое лицо.

\section{S u m m a r y}

Kuzmych $O$. Ya. Legal provisions regarding the participation of third parties in obligations to create a threat to life, health, property of an individual or property of a legal entity. - Article.

The article is devoted to the possible participation of third parties in obligations to create a threat to life, health, property of an individual or property of a legal entity, taking into account the specifics of legal regulation of the latter and the understanding of third parties as subjects of civil relations.

Key words: third person, natural person, legal entity, property, state, other person. 